Discussion Paper No. 98-41

Job Search Methods and Outcomes

John T. Addison, University of South Carolina

Pedro Portugal, Banco de Portugal 


\title{
Job Search Methods and Outcomes
}

\author{
by
}

\author{
John T. Addison, University of South Carolina \\ Pedro Portugal, Banco de Portugal
}

Zentrum für Europäische Wirtschaftsforschung (ZEW)

July 1998

\begin{abstract}
In this paper we investigate the process of job search, using a unique, large-scale data set for Portugal that allows us to assess the effect of job search methods on escape rates from unemployment and, in a new departure, the impact of job-finding methods used by the unemployed on earnings. In each case, the characteristics of workers receive careful attention. In addition, the effectiveness of the job search process is evaluated in terms of the periodicity of the resulting job match. Some emphasis is accorded the role of the public employment agency which, despite its frequency as a search vehicle, is found to have a low hit rate and to lead to low-paying jobs. Such jobs are also shorter lasting, only partly because they are more likely to be of a fixed-term nature. The policy backdrop is provided by the "employment chapter" of the Treaty of Amsterdam. Given our results, some concern naturally arises as to the capacity of the public employment agency to meet the targets set under European employment initiatives.
\end{abstract}




\section{Introduction}

The process of job search has received comparatively little attention in the job search literature, which has been more concerned with the determinants of the reservation wage in a framework that has often taken the arrival rate of job offers to be exogenous (e.g. Narandranathan and Nickell, 1985). Although search intensity has been modeled in a number of theoretical and empirical treatments, the tendency has been to treat search effort as a uniform activity (e.g. Lippman and McCall, 1976; Barron and Mellow, 1979). This is unsatisfactory given long-recognized differences in job search methods (e.g. Bradshaw, 1973), which clearly differ in their time and money costs, and suggestive evidence on the apparent effectiveness of some routes (notably, the informal channel of friends and relatives) and the seeming ineffectiveness of others (principally, the public employment service). Recently, however, the process of job search has attracted closer analytical scrutiny with a view to enriching, and ultimately testing, the basic search model and to guide policy discussion. ${ }^{1}$ The results have been mixed.

U.S. studies have the advantage of a measure of the time intensity of the various strategies used by job seekers - together with information on a variety of forms of employer contact - whereas the Canadian and British studies reviewed below have had to work with information largely limited to the occurrence of job search methods. ${ }^{2}$ Perhaps the best-known treatment is Holzer's (1988) analysis of the search behavior of unemployed workers aged 16 to 23 years from the Youth Cohort of the National Longitudinal Survey in 1981. In Holzer's model, search methods vary in both cost and productivity for any given individual - and across individuals, too, according to their human capital endowments, background, and location. In each period, unemployed individuals seek to maximize the sum of current and expected future utility by choosing a reservation wage and level of search intensity. Familiarly, search lowers current utility but increases the future utility of being employed by raising the arrival rate of job offers.

Each search method is chosen to equate its marginal costs and benefits. The Holzer model contains the reservation wage, which determines the probability

1 Devine and Kiefer (1991) offer a useful survey of the literature on job search strategies and the arrival rates of job offers.

2 The one exception to this statement is the study by Jones (1989), using an EUI survey of 1,000 unemployed individuals in 1982. 
of accepting an offer, and the set of search methods, which determine the offer probabilities (not wage offers). Search intensity is a function of the number of search methods and search costs depend on the frequency and time costs per unit of each search method. He distinguishes five such methods: friends and relatives, responses to newspaper advertisements, state employment agencies, direct employer contacts (without referral), and "other methods" which combine all other remaining methods given in the survey. He shows that the two most frequently used methods of search are friends and relatives and direct applications to firms, respectively, which are also the most time-intensively utilized. Furthermore, they are the most likely to result in job offers and acceptances, together yielding $67 \%$ of all reported offers and $74 \%$ of all accepted offers. Acceptances as a proportion of offers received are particularly high for the friends and relatives route $(81 \%)$.

Holzer's cet. par. analysis examines the determinants and outcomes of search. First, search intensity (here the number of search methods because of missing values for the hours expended variable) is modeled as a function of predicted offers, inter al. ${ }^{3}$ The relation is direct, suggesting that search intensity reflects expected returns to search. Second, disaggregated results are presented for each search method. The latter probit analysis of use of the five search methods indicates that predicted offers have positive coefficients for direct applications, newspaper advertisements, and "other", but negative coefficients for friends and relatives and the state employment agency. Holzer interprets the negative coefficient estimates as indicating that the low cost of the friends and relatives route justifies this route, while the state employment agency is used by those with few opportunities anyway. He interprets his results as indicating that the use of specific methods varies across individuals with different opportunities in the labor market. Finally, Holzer separately regresses ex post offers on first the number and then the type of search method used. Number of search methods used has a positive and statistically significant effect on the probability of receiving an offer. Of the individual search methods, only friends and relatives and newspaper advertisements have positive and statistically significant coefficient estimates, though Holzer $(1988,17)$ chooses to interpret the positive - albeit insignificant - coefficient for state employment agencies as noteworthy "given their reputation for low effectiveness."

3 Holzer $(1988,14)$ cautions that acceptance probabilities have the advantage of reflecting wage offers but the disadvantage of reflecting reservation wages as well. 
Holzer thus interprets his empirical results as favorable to the basic search model. But rather different empirical results were earlier reported in a similar model by Keeley and Robins (1985), using Equal Opportunity Pilot Projects (EOPP) data for 1980. (Four samples are identified in this study, only the results for married males being considered here.) Keeley and Robins seek to evaluate the effect of job search requirements under government transfer programs (separate requirements for UI on the one hand and requirements under programs such as WIN, AFDC, and food stamps, on the other) on job search behavior and unemployment. They find that job search requirements under UI and other public programs increase the number of methods of search both public and private - but have mixed effects on hours of search expended. And for a variety of measures of employer contact (namely, weekly rates of employer contacts, employer visits, and job applications) the effects are uniformly negative; in particular, large and statistically significant negative effects are recorded for UI. In terms of unemployment duration, search requirements do not lead to increased hazard rates, holding constant the number of search methods and search hours. Indeed, they reduce escape rates. On the other hand, higher rates of employer contacts, employer visits, and job applications have a strong positive influence on escape rates. These, then, are the most productive forms of job search and they are not stimulated by the search requirement. Accordingly, the authors speculate that altering the search requirement so as to include more direct employer contact could pay dividends in reducing joblessness.

If these results are not contrary to the search model per se - only to Holzer's number of search methods construct - potentially more negative results are reported by Blau and Robins (1990), who also use EOPP data for 1980. This study focuses on on- and off-the-job search and to this extent is more directly related to a paper by Holzer (1987) on employed and unemployed search by youths, in which it is reported that unemployed job seekers are more likely to gain new employment than their employed counterparts. This result is explained by the higher levels of search effort - as in Holzer (1988), measured by number of search methods, plus the time spent on each - expended by the former group. Familiarly, differential search intensity is linked by Holzer to the higher search costs of the unemployed by virtue of foregone earnings. Higher 
search costs imply lower reservation wages, and Holzer finds that these are indeed lower relative to the offered wage for unemployed job seekers. ${ }^{4}$

Yet Blau and Robins (1990) obtain exactly the opposite result. Their treatment investigates choice of search method, choice of number of firms contacted, the rate at which job offers are generated given the contact rate, and the decision to accept an offer given the offer rate. The authors identify the same five job search methods as Holzer plus a sixth, namely, private employment agencies. Descriptive statistics reveal that direct applications to employers and advertisements generate the highest number of contacts, that private employment agencies and direct applications yield the most offers, and that friends and relatives and direct applications have the highest job-finding rates. In each case, the reported values are higher for the employed than the unemployed job seekers. In terms of effectiveness, measured by offers and acceptances per contact, friends seemingly dominate other routes, as in Holzer.

The authors model job finding probability per method as the product of the conditional acceptance probability, the conditional offer probability, the conditional contact rate, and the probability of using the method. The reduced-form equations for each of these components take account of the fact that the users of a particular method of job search are not a random subset of all searchers. Results are presented for all search methods combined, separately for employed and unemployed job seekers, as well as differences in search outcomes by method of search.

Among the more interesting general results are that UI recipients use more methods of search but make fewer contacts and receive fewer offers than nonrecipients; that blacks use more search methods but make fewer contacts and receive/accept fewer offers than do whites; and that human capital variables have mixed effects with, for example, education increasing the number of search methods used, contacts obtained, and offers received but reducing the conditional acceptance rate. As far as differences between employed and unemployed job seekers are concerned, all conditional probabilities other than the acceptance rate are higher for the former.

4 Our analysis of Portuguese stock data revealed few overt differences between on- and off-the-job search. Our inquiry will focus on unemployed search alone, which allows us to draw comparisons between the stock and flow components (where the latter can only be defined for unemployed search). For further U.S. evidence on unemployed and unemployed search, see Blau (1992). 
This brief review of the U.S. evidence does not provide much support for the public employment service, a conclusion reinforced by the continued decline in its utilization since 1970 despite the increase in the number of prime-age job seekers. Between 1970 and 1992, the share of unemployed and employed job seekers using state agencies declined from 30.2 to $22.6 \%$ (Ports, 1993, 65; see also Bishop, 1993). Indeed, the situation is even bleaker if U.S. critiques of the operation of the state agencies are to be believed. Thus, for example, Wielgosz and Carpenter (1987) have charted the complaints of inadequate screening of referrals, sluggish delivery, and "irrelevance". Such charges are of course not confined to the U.S. but may be less relevant to the experience of other countries which record greater use by job seekers of the public employment service, such as Canada and Britain where (male) utilization rates were $56 \%$ in 1983 and 83\% in 1993, respectively.

Analysis of Canadian data by Osberg (1993) has focused on the selection issue and in particular upon the possibility that the clientele of the public employment service might have fared (even) worse had they not in fact used this job search method. In his longitudinal analysis of the Canadian Labor Force Surveys for 1981, 1983, and 1986 - chosen to pick up different points in the cycle - Osberg contends that sample selectivity considerations are indeed important in explaining the probability of escaping from unemployment.

Osberg's data contain information on eight job search methods (in January of each year) and job finding success (in February of each year). His simple logit model regresses job-finding success on seven job search methods, inter al., where "other" search methods are treated as the omitted category. This procedure is only necessary in the absence of multiple search methods (where the categories are not self-exclusive), which is clearly not the case. The novelty of the exercise is the incorporation of a selection term. It is argued that job offers are produced by some mix of individual effort and personal contacts and that individuals differ in the latter unobserved (continuous) social contacts variable. Only the selection of individuals into public service employment is modeled rather than simultaneous self-selection across all job search strategies. Although the U.S. studies would indicate that the latter approach might not be practicable, the issue of the dissonance between search method and job-finding method remains.

In any event, and focusing here on his results for males, Osberg reports a mixed pattern of coefficient estimates for the Canadian public service employment agency by year. In 1981 (when the unemployment rate stood at 8.3\%), the coefficient is negative for both the previously short- and long-term unemployed 
and the selection variable is actually positive For 1983 (13.7\% unemployment) the coefficient for public service employment is negative and statistically insignificant for the short-term unemployed and positive and significant for the long-term unemployed. The selection term is meantime positive and insignificant for short-term and negative and significant for long-term unemployed. Finally, in 1986 (10.7\% unemployment) the coefficient for public service employment is negative and insignificant for both types of unemployed individuals and the selection correction term negative and statistically significant for each. Osberg speculates that sample selection bias is not as well captured in 1981 (as in 1983 and 1986), and argues that in bad markets the long-term unemployed, if not their short-term counterparts, do gain significantly. The case of intermediate markets is unclear, at least for males. His basic conclusion, then, is that even if the public service does not work in tight labor markets when job seekers can find work on their own, they nevertheless perform a valuable safety-net function in recession for long-duration male workers "who have exhausted their normal job search methods" (Osberg, 1993, 366).

Finally, as far as the other job search methods are concerned, and subject to our caveat about multiple job search methods, Osberg is only able to identify consistent job finding success for direct approaches to employers.

More optimistic results for the British public employment service (or "Jobcentres") are reported by Gregg and Wadsworth (1996), in a study that uses Labour Force Survey (LFS) stock data for the interval 1984 to 1992, and quarterly LFS flow data for 1992. (Our own treatment of Portuguese flow data fairly closely resembles that of Gregg and Wadsworth.) We shall focus on their analysis of the flow data (for males) because it seeks to evaluate the effectiveness of the various search methods, simply noting here that their stock analysis reveals, inter al., that use of the public employment service rises in recessions and falls in the recovery phase, as indeed do the total number of search methods used.

Gregg and Wadsworth's descriptive data for 1992 indicate that the media (advertisements) and the Jobcentre are the two most popular search methods, followed by friends and relatives. These search routes also record among the highest percentage of successful placements, their comparatively low hit rates (of around 2.5\%) being more than offset by their higher frequency of use. In estimating the probability of successful transitions by job search method, the authors' probit analysis shows that direct applications, advertisements, and the Jobcentre each have positive and statistically significant coefficients. Indeed, 
the estimated marginal effect of using a Jobcentre is to reduce the average duration of joblessness by approximately 3 months, cet. par. (Despite the use by unemployed workers of multiple job search methods, Gregg and Wadsworth - like Osberg (1993) - make use of an omitted category of "other" search methods. The practical implication of this specification is that when individuals use, say, both the public employment agency and "other" methods one cannot distinguish this situation from one in which "other" methods are not pursued.)

Other results of interest from this transitions equation are the increasingly negative effect of job search duration, the fact that the Jobcentre coefficient estimate is highest among the long-term unemployed, the significant positive effect of direct applications over both short- and long-term unemployment, and (in one specification) the deployment of a selection term. In the latter context, the authors follow Osberg (1993) in attempting to model the selection of workers into Jobcentre use (alone); identification is achieved by excluding regional dummies from the transition probit and including them in the Jobcentre-use probit. The coefficient estimate for the selection term is positive but insignificant.

Finally, Gregg and Wadsworth model the probability of using the various search methods conditional on making a transition to work. They find that duration of joblessness is positive for the Jobcentre route, negative otherwise. Interestingly, the effect of being a UI benefit claimant is negative and significant for the Jobcentre, suggesting that claimants are less likely to have got work through that agency. The opposite is the case for direct applications to firms. Low-skilled workers only appear to gain if they use a Jobcentre, and conversely for graduates, with direct applications benefitting all skill groups.

This more positive view of the public employment service certainly contrasts with the broad U.S. evidence and is hinted at in a number of other British studies. The latter have also tended to be more critical of the underlying search model and the disincentive effects of UI in particular (see, for example, Jones, 1989; Schmitt and Wadsworth, 1993). Given the dissonance between the U.S. and British evidence, the relatively sparse literature on the process of job search, and recent policy shifts in Europe seeking to build on the public sector employment service, it seems well worthwhile to examine another country's experience - here Portugal - even if the data in some respects continue to fall short of those used in the best U.S. studies because of inadequate information on search intensity and reservation wages. 
In what follows, we present results on the impact of job search method on transitions from unemployment, examine the probability of job finding through a specific search route versus remaining unemployed, and provide information on baseline hazard rates conditional on finding a job through a specific search method (and thence differential hit rates). In a new departure, we examine the wage outcomes resulting from different job-finding methods, and the process of wage determination across job-finding methods. In addition to transitions into employment and wage outcomes, we also for the first time present evidence on the success of the job match by relating transitions from employment to unemployment to the way in which the job was located. Surprisingly, the literature has examined neither the wage nor the transitions to unemployment aspects of the job search process. We use a common data set in stock and flow modes (rather like Gregg and Wadsworth, 1996), which approach also allows us to address the duration of jobs found through the public employment agency. To anticipate our findings, we report that the Portuguese evidence more closely accords with the U.S. than the British experience as far as the effectiveness of the public employment service is concerned.

\section{Data}

The data used in this inquiry are taken from the quarterly Labor Force Survey(s) (Inquérito ao Emprego) of the Portuguese National Institute of Statistics (Instituto Nacional de Estatistica). This nationally representative survey inquires of a random sample of individuals their current labor market status and past labor history. The Survey is thus identical to, say, the Current Population Survey in sampling the population of members of a state at a given time and their elapsed durations in that state.

The Survey has a quasi-longitudinal capacity. Each individual is interviewed during six consecutive quarters, enabling us to track transitions across states employment, unemployment, and inactivity - for up to five quarters. Transition rates are obtained by simply identifying those in a given state, and their elapsed duration, who move out of that state over the subsequent quarter. The transition rates can simply be computed as the number of individuals of a given elapsed duration that move into a different state during the subsequent quarter divided by the total number of individuals with the same elapsed duration in that state. In particular, transition rates out of unemployment into employment are obtained by simply identifying those unemployed, and their elapsed duration, who move out of unemployment into employment in the subsequent quarter. Conditional probabilities of exiting unemployment can be computed at 
different durations to yield quarterly hazard rates, namely, the pattern of reemployment probabilities by unemployment duration.

This type of sampling plan (observation over a fixed interval - see Lancaster, 1990) will be used in a "flow" analysis to identify the contribution of the various job search methods, described below, to escape rates from unemployment, 1992-96. ${ }^{5}$ It will also be used to assess the role of individual characteristics in determining a successful job-finding method. Since we can also track all transitions out of employment into unemployment, we can offer a measure of the "effectiveness" of the match produced by a particular job-finding method for the period 1994-97 (job-to-job transitions can only be identified after 1993). Finally, the data will also be used in more conventional stock fashion to assess the contribution of job-finding methods to earnings in 1997, as well as to offer a cruder check on the effectiveness of the public employment service (than permitted by transitions out of employment).

From the perspective of job search methods, the Survey identifies eleven separate search "strategies". ${ }^{\circ}$ These were duly collapsed into seven separate measures: direct applications on the part of the unemployed worker to firms (direct approach), pursuit of informal channels (namely, friends and relatives), use of the media (advertisements), contacting the public employment service, self-employment, taking examinations, and a residual category of "other" methods to include the use of private employment agencies. Some amplification of the self-employment category is required since it necessarily refers to activities preparatory to self-employment proper. Such activities include attempts to get financing or equipment, or seeking to rent space to run a business. Less obviously, the category of "examinations" requires modest amplification because it encompasses other than actual tests to include interviews with employers which may be viewed as an intermediate stage in the job search process.

5 The choice of sample period, 1992-96, is dictated by changes in survey methodology after the first quarter of 1992. These included new sampling procedures and revised definitions of the labor force status of the individual.

6 The 11 jobs search methods are the public employment service, private employment agencies, direct approaches to employers, use of friends and relatives, placing and responding to advertisements, reviewing advertisements, examinations, taking tests and interviews, looking for land or space for a business, seeking licences or financial resources, and "other." 
Correspondingly, the Survey identifies twelve (collapsed into eight) job-finding methods. The additional category identifies situations in which the unemployed worker is contacted by an employer. This new category covers direct recruitment strategies other than advertisements. In the case of job-finding methods, the classifications of self-employment and examinations mean precisely that and hence do not exactly match the job search methods of the same nomenclature. In the analysis of transitions (flow analysis), the job search and job finding methods relate to successive quarters. For the stock analysis, job-finding methods refer to the current job, which may in the limit have been held since labor market entry.

Each job search and job-finding measure will be employed in the flow analysis. For the stock analysis our wage regressions have perforce to omit the category of self-employment because the Survey does not yield data on the earnings of the self-employed.

The Survey contains in addition to the job search and job-finding methods, information on the UI status of the unemployed individual. In the present treatment, we simply use a dummy variable to capture the effect of UI. Note that this does not lead to a problem of endogenous sample stratification bias because we are able to observe both elapsed duration and transitions out of unemployment for both recipients and nonrecipients. Other variables in the survey include data on the individual's age, marital status, disability, level of schooling, past receipt of vocational training, tenure on the previous and current job, overall labor market experience, number of jobs held, occupational status, reason for job loss, industry, and region of residence. These are conventional enough, so that only the (monthly) wage variable requires some clarification. Wages, as measured by the survey, are not continuous but rather categorical, comprising 13 wage intervals. Left- and right-censoring characterize the bottom and top intervals. The estimation of the wage equations can be developed using a grouped regression model and assuming a parametric distribution - here the lognormal - for the error term.

The restrictions employed in the flow analysis were that the individual be unemployed (or employed in the case of transitions into unemployment) at the time of the survey. Only transitions into unemployment (and employment) are considered. ${ }^{7}$ The remaining restrictions - used in both the flow and stock

7 Transitions into various types of employment and into inactivity are considered in Portugal and Addison (1997). 
analyses - were that the individual be aged between 16 and 64 years and resident in mainland Portugal.

\section{Methodology}

In order to analyze the quarterly transitions from unemployment into employment, given that the information on elapsed unemployment duration is provided in months, we shall specify a discrete time duration model. Calendar time is divided into $\mathrm{k}$ intervals $\left[0, \mathrm{c}_{1}\right),\left[\mathrm{c}_{1}, \mathrm{c}_{2}\right), \ldots\left[\mathrm{c}_{\mathrm{k}-1}, \infty\right)$, where $\mathrm{c}_{\mathrm{t}}$ define the limits of the intervals. ${ }^{8}$ Discrete time (unemployment duration) $\mathrm{T} \in\{1,2, \ldots \mathrm{k}\}$ is observed, with $\mathrm{T}=\mathrm{t}$ denoting exit into employment within interval $\left[\mathrm{c}_{\mathrm{t}-1}, \mathrm{c}_{\mathrm{t}}\right.$ ). The discrete hazard function, depicting the conditional probability of an individual exiting into employment at interval $t$, giving that he/she stayed unemployed until $\mathrm{t}$, is given by

$$
\lambda(t \mid x)=P(T=t \mid T \geq t, x), \quad t=1,2, \ldots, k-1
$$

where $\mathrm{x}$ denotes a vector of covariates.

Assuming a proportional hazards (or Cox) specification for the effects of the covariates, the grouped proportional hazards model (see Prentice and Gloeckler, 1978) is defined by

$$
\lambda(t \mid x)=1-\exp \left[-\exp \left(\gamma_{t}+x^{\prime} \beta\right)\right] .
$$

The parameters of this piecewise baseline hazard function result from

$$
\gamma_{t}=\log \left[\int_{0}^{c_{t}} \lambda_{0}(u)-\int_{0}^{c_{t-1}} \lambda_{0}(u)\right]
$$

where $\lambda_{0}(u)$ denotes the underlying continuous baseline hazard function.

If, however, we wish to distinguish between distinct job search methods that are instrumental in job finding, we can specify a cause-specific hazard function, where we model the conditional probability of exiting from unemployment into employment through a specific job finding method $j$, as 


$$
\lambda_{j}(t \mid x)=P(T=t, J=j \mid T \geq t, x),
$$

or, more specifically, under the proportional hazards assumption

$$
\lambda_{j}(t \mid x)=1-\exp \left[-\exp \left(\gamma_{j t}+x \hat{\mathrm{a}}_{j}\right)\right] .
$$

If, in addition, we are interested in the hit rates of each job search method, we can condition the analysis on the occurrence of a specific job search method in the previous quarter

$$
\ddot{e}_{j}(t \mid x)=P\left(T=t, J=j \mid J_{t-1}=j, T \geq t, x\right),
$$

where $J_{t-1}=j$ denotes that the job search method $j$ was used in period t -1 .

When we turn to the estimation of the choice of the job finding method, we use a multinomial response model for which the dependent variable is a $\mathrm{J}$ dimensional vector of indicators $y=\operatorname{vec}\left\{y_{j}, j=1, \ldots, J\right\}$, with

$$
y_{j}=1\left\{y_{j}^{*} \geq y_{k}^{*} \text { for } k \neq j\right\} .
$$

That is, $y_{j}=1$ if and only if, $y_{j}{ }^{*}$ is the largest across the alternative job finding methods. The latent variable $y_{j}{ }^{*}$ is assumed to be generated by a linear model

$$
y_{j}^{*}=x^{\prime} \beta_{j}+\varepsilon_{j},
$$

leading to the conventional multinomial logit model if $\varepsilon$ is assumed to have an extreme value distribution.

The wage information provided by the Portuguese household survey is given in thirteen distinct intervals. In other words, wages are grouped into 13 ordered classes. Fortunately, the limits of the intervals are known, leading naturally to a standard grouped dependent variable model

$$
\ln w=\sum_{i=1}^{I} 1\left\{x^{\prime} \beta+v>a_{i}\right\}
$$

The latent variable $\ln w^{*}$ is assumed to be determined by

$$
\ln w^{*}=x^{\prime} \beta+v
$$

and is known to fall in one of the $\mathrm{I}+1$ ordered intervals $\left(0, \mathrm{a}_{0}\right],\left(\mathrm{a}_{0}, \mathrm{a}_{1}\right], \ldots,\left(\mathrm{a}_{1}, \infty\right)$, which correspond to prespecified log wage intervals. If $v$ is assumed to be

8 In practice, we define eleven duration intervals corresponding to $1,2,3,4,5,6,7-9,10-12,13$ 18,19-24 and more than 24 months. 
normally distributed, the model will correspond to a conventional grouped lognormal dependent variable model.

Finally, employment to unemployment transitions can also be defined in terms of a latent variable model

$$
V^{*}=x^{\prime} \beta+\omega
$$

where $\mathrm{V}^{*}$ can be viewed as the unobserved value of staying in a given state (say unemployment). The binary response model can then be expressed as an indicator of the positivity of the latent variable

$$
V=1\left\{x^{\prime} \beta+\omega>0\right\} \text {, }
$$

which will lead to the binary logit model if $\omega$ is assumed to be extreme-value distributed.

\section{Findings}

We begin our analysis with descriptive information from the quarterly flow data, covering the interval 1992-96. The first three columns of Table 1 present the search methods and success rates of unemployed job seekers. Column 1 gives the number of individuals using any given search method. The public employment agency is evidently the most numerous category, closely followed by the use of friends and relatives and direct applications to employers. But individuals use multiple strategies, the average number of search methods being 2.05. ${ }^{9}$ Column 2 gives the number and share of those using a given strategy that are employed in the subsequent quarter. The differences in success rates fall in the relatively narrow range of $13.8 \%$ (advertisements) to $18.5 \%$ ("other", including private employment agencies). We cannot conclude from this information that any one search strategy is more successful than another because, as we have seen, job seekers use more than one search method. More information in this regard is conveyed by the "hit rates" shown in Column 3, which more directly link the job search strategies with job finding. The hit rate is given by the number of individuals reporting being employed in quarter $t$ via a given method divided by those who were using that method in period $\mathrm{t}-1$. Rather marked differences now characterize the sample. With the exception of

9 But note that an individual has to use at least one search method during the last 30 days to be classified as unemployed. 
self-employment - which may or may not represent a truly successful transition and where the number of transitions is modest - the use of friends and relatives emerges as the most successful strategy, followed at some distance by direct applications to firms. The balance of the search methods have low hit rates in the range $1.2 \%-1.9 \%$, that of the public employment agency being in the middle of this range. Finally, Column 4, simply identifies those who found a job by a particular method irrespective of the job search strategy used in the quarter preceding reemployment. Again, almost $70 \%$ of those finding work do so via the channels of friends and relatives and direct approaches to firms. The fact that the number of individuals is now much higher than in Column 3 means that an important proportion of the unemployed find work through methods that they were not using in the previous quarter. ${ }^{10}$

Table 1 abstracts from the personal characteristics of those using the various job search strategies. Table 2 investigates the probability of escaping from unemployment between successive quarters controlling for such characteristics. Unlike the British research reviewed earlier in Section I, no omitted search category is deployed because of the use of multiple job search strategies on the part of the unemployed job seeker. From the table we can therefore merely state that some search strategies appear to work in raising transitions as compared with the artificial situation of no search methods. Such successful job search methods are direct applications to employers, taking examinations, and self-employment. There is no indication that use of the other search methods materially raise hazard rates (again compared with the use of no search method).

The behavior of the controls is much as expected. Thus schooling, the number of jobs previously held, and the necessarily anticipated termination of a fixed-term contract are all associated with higher escape rates, while UI recipiency, tenure on the previous job, age, being male, and labor market entry (denoted "first job") all serve to depress escape rates. Less obvious perhaps are the lower escape rates of male and white-collar workers and the failure of being either handicapped or married to influence escape rates. The year dummies broadly indicate that flows out of unemployment are procyclical (1992, a low employment year, being the omitted category). The regional dummies capture

10 Another source of disparity between Columns 3 and 4 has to do with the latter containing some workers who become employed as a result of direct approaches on the part of firms, though the numbers involved here are small. 
lower unemployment rates in regions with large metropolitan areas (North and Lisbon) and in the Algarve which depends heavily upon tourism.

Not shown in Table 2 is the eleven-segment baseline hazard function. Familiarly this displays strong negative duration dependence. For a male unemployed individual who is aged 30 years and has 9 years of schooling (and who corresponds to the omitted categories in all other respects), the quarterly transition rates into employment decline from $44 \%$ after one month of unemployment to $25 \%$ at six months, to $18.5 \%$ at 13 months, and to 17 percent after 25 months. We will subsequently provide individual baseline hazards for the various job search methods and for the conditional hazards model, where the differences in the height of the baseline hazards directly index differential hit rates.

Table 3 looks at disaggregate hazards for successful job search methods, focusing on the role of individual characteristics in determining successful transitions into reemployment. The reference category in this duration model is of course the still-unemployed worker. The most important results are as follows. First, as is to be expected, UI recipients are less likely to make a success of the various job search methods than are nonclaimants. The major exception in this regard is the public employment agency, where the coefficient estimate for UI is both positive and statistically significant. (This result is most likely a consequence of the requirement that the unemployed be registered with the public employment agency in order to collect unemployment insurance benefits, and therefore does not have a behavioral interpretation). ${ }^{11}$ Second, higher levels of schooling do not improve the reemployment prospects of those securing jobs through a public employment agency or for that matter methods other than advertisements, "other," and, most obviously, those finding work through examinations. Third, direct search notably fails to improve the reemployment prospects of older workers vis-à-vis their younger counterparts and definitively ill suits white-collar workers. Fourth, males gain most from direct approaches to employers and the use of informal networks, which job finding routes are also most important for those with greater job holding in the past. Fifth, labor market entrants face fewer difficulties in job finding when they use informal networks and appear to increase their chances of employment

11 One might be tempted to ascribe the other positive UI coefficient estimate - attaching to direct approaches from firms - to recalls and the absence of active job search in such circumstances, but as a practical matter temporary layoffs are not formally encountered in Portugal. 
if they take exams or interviews, though this latter effect is not statistically significant. The bottom line is that rather different (observed) characteristics do after all define the success of individuals using the various job-finding methods, a theme to which we shall return.

Figure 1 illustrates the baseline hazards for the job-finding methods given in Table 3. The baseline hazards again pertain to a male individual aged 30 years with the mandatory schooling level of 9 years and where all the other variables assume their reference values. The height of the various functions reflects both the frequency of use and the success of the job-finding methods. The main result is the negative duration dependence attaching to the direct approach, the use of friends and relatives, and advertisement. No such evidence of reduced escape rates with unemployment duration is detected for the public service employment case, which is consistent with some individuals using this route after other job search methods have been tried without success. As far as the remaining job-finding methods are concerned, the limited sample sizes serve to limit the inferences that can be drawn concerning duration dependence.

Figure 2 presents corresponding results for the conditional hazards, that is, the pattern of escape rates by jobless duration interval pertaining to job finding methods that were also the job search strategies pursued during the previous quarter. Here, as noted earlier, the height of the functions - only four are given because of the reduction in sample sizes - now provides information on the respective hit rates of the job search methods. The relative success of the use of informal methods of job search and advertisement is apparent as is the relative failure of the public employment service route. Consistent with Figure 1 , all the successful job search methods other than the public employment service display negative duration dependence.

If the above results do not augur particularly well for the effectiveness of search and placement conducted through the public employment service, we would stress that our findings are otherwise largely conformable with British and other results. One such link pertains to the search intensity literature. That is, we find that search intensity, as proxied by number of searches (but see section I), is positively related to the overall level of unemployment, to the individual's jobless duration, and to UI recipiency. These are familiar results - even if the UI finding is contaminated by the registration requirement. Furthermore, we find that labor market entrants use fewer search methods, while the opposite is true for males and more educated job seekers. These and other results are contained in Appendix Table 1 for a truncated Poisson regression - truncated at one because individuals employing zero search methods in the last 30 days are 
not considered unemployed and are thus not observed - but are not further addressed here.

We next turn to findings from the stock data for 1997. Success of the respective job finding methods is assessed in terms of the resulting earnings levels. Because there can only be one job-finding method, the earnings regressions in Table 4 method use an omitted category, namely, "other," which it will be recalled includes the use of private employment agencies. Column 1 presents findings for a parsimonious specification that includes only the job finding methods. It provides a rather different picture of the success of job search methods than is evident in the flow data (see Table 2). Thus, the two most popular job search/job-finding methods of direct approaches to employers and the use of the informal network of friends and relatives are markedly less successful in terms of earnings (than the omitted category). The positive role of examinations is correspondingly elevated in importance. The one constant, however, is the seemingly abject performance of the public employment agency. Workers that report having found a job through the public employment service receive $38.5 \%$ less than those who obtained their job through "other" methods.

Our earlier findings point to the importance of individual characteristics to unemployment outcomes. Column 2 of Table 4 confirms that the same obtains for earnings. The negative coefficient estimates for the relevant five job-finding methods are substantially reduced in absolute magnitude with the inclusion of the human capital, demographic, and other controls. Nevertheless, the relative earnings disadvantage attaching to the public employment agency route remains twice that of its closest contenders (and is $19.3 \%$ less than "other" methods). The magnitude and sign of the coefficient estimates for the human capital controls (vocational training, schooling, and experience) are utterly conventional, and the effect of full-time employment is predictably strong. The pattern of industry differentials are also unsurprising, the omitted category being agriculture.

Column 3 of Table 4 adds "atypical work" (i.e. fixed-term contracts) and tenure on the job to the list of regressors. Both arguments can be interpreted as an outcome of the job search strategy; for example, of jobs found through the public employment agency which tend to be shorter lasting. In fact, as shown in Appendix Table 2, jobs found through the public employment service are, cet. par., disproportionately of a fixed-term contract nature. Specifically, if a job was found through this route it is 3.6 times more likely to be a fixed-term contract, as compared with the "other" category. Not surprisingly, therefore, 
when fixed-term contracts and tenure on the job are included in the earnings regression, the relative earnings disadvantage associated with jobs found through this route is very much attenuated. Yet this reduction is quite artificial.

The more important differences in earnings function across job-finding methods are charted in Table 5. The most notable feature of the table is the differential returns to the human capital measures for jobs secured through the public employment service. With a few minor exceptions, the coefficient estimates for vocational training, schooling, tenure, and experience are consistently lower for this job-finding route than the other methods. Also of interest is the negative relative wage differential attaching to jobs located through the state agency in public administration, which is not a uniformly low-paying sector. Even in the case of fixed-term contracts, such jobs typically pay somewhat less if found through the public employment service.

Table 6 documents the likelihood of choosing a particular job finding method. The reference category is "other". Among the more important differences between methods are the following. First, people with lower levels of schooling are more likely to find work through the public employment service, though the likelihood is not markedly different from that obtaining in the cases of direct approaches to firms and informal methods. Second, workers with lower levels of labor market experience are much less likely to find work through this route. Third, females are much more likely to locate jobs through the state agency than through any other method. Fourth, public administration attracts a disproportionate share of those state agency placements, though again this is even more marked in the case of those finding work through examinations. In very broad terms, these results from the stock of employment are consistent with those reported earlier in Table 3 pertaining to flows into employment.

The data on the number of events provided at the head of Table 6 indicate that just 3.8\% (=[444/14436).100) of employees in 1997 reported that they found work through the public employment service, which may be compared with the corresponding value of $10.4 \%(=[124 / 1192] .100)$ provided in Table 1 . The obvious implication, alluded to earlier, is that such jobs are shorter lasting. ${ }^{12}$

12 Data on mean tenure from the stock sample - 2.6 years for jobs secured through the public employment service - confirm this: direct approach, 9.3 years; friends and relatives, 9.7 
Table 7, which uses the flow data for 1992-96 to examine transitions from employment into unemployment, casts further light on this issue. Column 1 of the table shows that compared with the omitted category of "other" methods, jobs found through the public agency are almost four and one-half times more likely to be associated with transitions into unemployment. Solicitations from employers and advertisements are also associated with higher relative transition rates but the effect is altogether less pronounced than for public employment service jobs. On the other hand, those finding jobs through the examinations route are only one-third as likely (as the omitted category) to transition into unemployment, while direct approaches to employers and informal methods have no discernible impact. Column 2 of the table shows that the higher turnover of jobs secured through the public agency persists - such jobs are now just over twice as likely to end in unemployment than the omitted category when tenure and atypical employment are included as additional regressors. Finally, it can be seen that part-time employment is not associated with a higher transition rate; in fact, the opposite result holds. It is difficult to resist the conclusion that jobs found through the public agency are relatively poor jobs, other things being equal.

We have argued that the effectiveness of the public employment agency in Portugal is low. But the observed outcomes are the result of a number of factors that are difficult to disentangle. The first is genuine ineffectiveness. Second, the pool of jobs reported to the agency by employers is typically small and comprises low-paying jobs that are difficult to fill. In this sense, the agency can be likened to a search method of last resort on the part of employers. Moreover, employers tend to avoid public employment service placement unless they can obtain some type of subsidy for hiring, say, inexperienced youth (and other labor market entrants). Both factors - as well as inefficiency hint at a potentially severe reputational effect associated with the Portuguese agency. Third, there is the "active" component of manpower policy undertaken by the state agency, whereby it places workers in so-called "occupational programs". These are jobs paying the minimum wage and are typically in public administration. Here we may have employment of last resort. In this case, however, our results do not appear to be explained to any material degree by this route of employment of last resort because they are insensitive to netting out minimum wage jobs and employment in public administration. Fourth, all workers who draw unemployment benefits must register with the public

years; advertisements, 6.7 years; employer solicitations, 6.1 years; "other," 9.3 years; and examinations, 15.3 years. 
employment agency. Here the selection mechanism involved favors workers who satisfy the eligibility requirement. In this case, selection is likely to go the "other way" because UI-insured workers have longer work histories and greater attachment to the labor force than an unemployed individual taken at random. In other words, given the fulfillment of the eligibility requirement and other things equal, they are more likely to find a job than a randomly selected unemployed individual.

In the light of the above, although selection is implicit in measures of the outcome of public employment service mediated job search and job finding, the identification restrictions necessary to account for unobservables are almost invariably arbitrary. Thus, we still think it sensible to provide a reduced-form interpretation of the point estimates for public service employment; that is, as picking up both a low level of effectiveness and selection considerations. This more muted conclusion is warranted by the data at our disposal which preclude our being able to distinguish between direct effects and the component indicating how those using the agency would have fared had they not pursued this job search route.

\section{Concluding Remarks}

Perhaps the major finding of this empirical inquiry has been that the public employment service has a low hit rate and leads to jobs that do not last, that are lower paying, and that reward observed human capital attributes conspicuously less than do other job finding routes. These results do not appear to be ultimately determined by that agency's role as an instrument of "active" manpower policy, directing workers to low-paying public sector jobs of an employment-of-last-resort nature. Although much more work is required on the distinction between the agency's placement and employment functions, our basic results carry through after netting out minimum wage jobs and/or atypical (i.e. fixed-term) jobs.

An unsettled issue in this inquiry and all other investigations of this genre is the question of selection into public employment service directed job search - and indeed other job search methods. In short, how would unemployed job seekers have fared had they not used this agency as a search vehicle. Given the largely arbitrary nature of identification restrictions - here, as elsewhere - we have necessarily concluded that our point estimates are a mix of main effects (pointing to the relative inefficiency of the vehicle) and selection, while 
cautioning that the selection mechanism does not always work in the direction of producing lower escape rates/earnings.

The next issue is the efficacy of the other search methods and job-finding routes. Although we subscribe to the premise that workers choose those search methods which they perceive as having the greatest return, there is mixed evidence on the success of these methods. To be sure, the crude hit rates for direct search methods and the use of informal networks are higher than those reported in, say, the British literature (e.g. Gregg and Wadsworth, 1996) but the employment gains are muted and also do not necessarily translate into higher earnings. We would surmise that these results reflect the long-term nature of Portuguese unemployment, the sources of which have been analyzed by Blanchard and Portugal (1998). There is at least the suggestion in our evidence of a tradeoff between job search effectiveness, as measured by reemployment transitions, and the wage and employment outcomes.

The problems of such labor markets return us to the policy arena. Under the October 1997 Treaty of Amsterdam, an employment chapter was inserted into the treaties establishing the common market. The goal was to secure a "high level of employment," reducing Community unemployment of around 18 million (10.6\%) and increasing employment rates (from their rather low level of $60.4 \%$ ). To this end, guidelines have been set for member states' employment policies. ${ }^{13}$ The guidelines ultimately adopted in Council eschew specific targets for job creation but they do contain concrete elements. Thus, member states are to ensure that all unemployed persons are offered a job, training, or some other work-related activity within 12 months (or 6 months in the case of young people under the age of 25 years). Also, the number of unemployed who are offered training is to increase from the current EU average of $10 \%$ to $20 \%$ or more within five years. Member states are to draft their own employment action programs based on these guidelines.

To this end, Portugal presented its national jobs plan in March of this year. The bulk (almost 70\%) of the resources committed (Esc. 211 billion) under the plan are directed toward the unemployed: two-thirds for youth unemployment and

13 Apart from the unemployment measures noted below (geared to "creating a culture of employability"), the remaining guidelines seek to "promote a culture of entrepreneurship," to encourage new forms of working while protecting employment security, and to increase the participation rates of women. 
one-third for long-term unemployment. ${ }^{14}$ The public employment service is assigned a key role in securing these goals. But, as we have seen, less than $4 \%$ of the current stock of employed workers who engaged in unemployed job search found work via the public employment service route and that, other things being equal, it does a poor job in placing workers in long-lasting jobs. ${ }^{15}$ Given its past record, it is hard to resist the conclusion that undue reliance is being placed on the public employment service.

14 The residual $30 \%$ of the monies is to go to further education and training of the currently employed.

15 Allowing for employed as well as unemployed job search, just $1.8 \%$ of the stock of currently employed found work through the public employment service. 


\section{References}

Barron, John M., and Wesley Mellow. "Search Effort in the Labor Market." Journal of Human Resources 14 (Summer 1979): 389-404.

Bishop, John. "Improving Job-Worker Matching in the U.S. Labor Market." Brookings Papers on Economic Activity, Microeconomics Volume 1, 1993, pp. 335-400.

Blanchard, Olivier, and Pedro Portugal. "What Hides behind an Unemployment Rate: Comparing Portuguese and U.S. Unemployment." Unpublished Paper, Banco de Portugal, April 17, 1998.

Blau, David M. "An Empirical Analysis of Employed and Unemployed Job Search Behavior." Industrial and Labor Relations Review 45 (July 1992): 738-752.

Blau, David M., and Philip K. Robins. "Job Search Outcomes for the Employed and Unemployed." Journal of Political Economy 98 (June 1990): 637-655.

Bradshaw, Thomas F. "Jobseeking Methods Used by Unemployed Workers." Monthly Labor Review (February 1973): 35-40.

Devine, Theresa J., and Nicholas M. Kiefer. Empirical Labor Economics: The Search Approach. New York: Oxford University Press, 1991.

Gregg, Paul, and Jonathan Wadsworth. "How Effective are State Employment Agencies? Jobcentre Use and Job Matching in Britain." Oxford Bulletin of Economics and Statistics 58 (August 1996): 443-467.

Holzer, Harry J. "Job Search by Employed and Unemployed Youth." Industrial and Labor Relations Review 40 (July 1997): 601-611.

Holzer, Harry J. "Search Method Use by Unemployed Youth." Journal of Labor Economics 6 (January 1988):1-20.

Jones, Stephen R.G. "Job Search Methods, Intensity and Effects." Oxford Bulletin of Economics and Statistics 51 (August 1989): 277-296. 
Keeley, Michael C., and Philip K. Robins. "Government Programs, Job Search Requirements, and the Duration of Unemployment." Journal of Labor Economics 3 (July 1985): 337-362.

Lancaster, Tony. The Econometric Analysis of Transition Data. Cambridge: Cambridge University Press, 1990.

Lippman, Steven A., and John J. McCall. "The Economics of Job Search: A Survey. Parts I, II." Economic Inquiry 14 (June-September 1976): 155-189; 347-368.

Narandranathan, Wiji, and Stephen Nickell. "Modeling the Process of Job Search." Journal of Econometrics 28 (April 1985): 29-49.

Osberg, Laws. "Fishing in Different Pools: Job-Search Strategies and Job-Finding Success in Canada in the Early 1980s." Journal of Labor Economics 11 (April 1993): 348-386.

Ports, Michelle Harrison. "Trends in Job Search Methods." Monthly Labor Review 116 (October 1993): 63-67.

Portugal, Pedro, and John T. Addison. "Unemployment Insurance and Joblessness: A Discrete Duration Model with Multiple Destinations." Estudos e documentos de trabalho 1997-3, Banco de Portugal, 1997.

Prentice, R. L. and L.A. Gloeckler. "Regression Analysis with Grouped Survival Data with Application to Breast Cancer Data." Biometrics 34 (1978): 57-67.

Schmitt, John, and Jonathan Wadsworth. "Unemployment Levels and Search Activity." Oxford Bulletin of Economics and Statistics 55 (February 1993): $1-24$. 


\section{Tables}

Table 1: Job Search Method and Job-Finding Success Among the Unemployed, 1992-96

\begin{tabular}{|c|c|c|c|c|c|c|c|}
\hline \multirow{2}{*}{$\begin{array}{l}\text { Job search method } \\
\text { Direct approach }\end{array}$} & \multirow{2}{*}{$\begin{array}{l}\text { Number using } \\
\text { search method } \\
\text { in } t-1 \\
7,138\end{array}$} & \multicolumn{2}{|c|}{$\begin{array}{l}\text { Number (\%) finding } \\
\text { job in } t\end{array}$} & \multicolumn{2}{|c|}{$\begin{array}{l}\text { Number }(\%) \text { using a } \\
\text { job search method in } \\
t-1 \text { that report job } \\
\text { finding via that } \\
\text { method in } t\end{array}$} & \multicolumn{2}{|c|}{$\begin{array}{l}\text { Number }(\%) \text { employed } \\
\text { by job finding method } \\
\text { in } t\end{array}$} \\
\hline & & 1,211 & $(17.0 \%)$ & 305 & $(4.3 \%)$ & 501 & $(22.0 \%)$ \\
\hline Friends/relatives & 7,942 & 1,191 & $(15.0)$ & 597 & $(7.5)$ & 1,067 & $(46.8)$ \\
\hline Advertisement & 5,485 & 755 & $(13.8)$ & 106 & $(1.9)$ & 151 & $(6.6)$ \\
\hline Public employment agency & 8,325 & 1,132 & $(13.6)$ & 124 & $(1.5)$ & 154 & $(6.8)$ \\
\hline Self-employment & 151 & 25 & $(16.6)$ & 20 & $(13.2)$ & 179 & (7.8) \\
\hline Examinations & 2,061 & 275 & $(13.3)$ & 29 & $(1.4)$ & 113 & $(5.0)$ \\
\hline $\begin{array}{l}\text { Other (incl. private } \\
\text { employment agency) }\end{array}$ & 924 & 171 & $(18.5)$ & 11 & $(1.2)$ & 116 & $(5.1)$ \\
\hline Average number of search $n$ & 2.05 & & & & & & \\
\hline
\end{tabular}

Notes: See text

Source: Inquérito ao Emprego, 1992-96. 
Table 2: The Probability of Escaping Unemployment by Job Search Method, Piecewise Constant Hazards Regression, 1992-96

\begin{tabular}{|c|c|}
\hline Variable & Coefficient \\
\hline Direct approach & $\begin{array}{l}0.220 * * * \\
(0.043)\end{array}$ \\
\hline Friends/relatives & $\begin{array}{l}-0.002 \\
(0.043)\end{array}$ \\
\hline Advertisement & $\begin{array}{l}-0.038 \\
(0.050)\end{array}$ \\
\hline Public employment agency & $\begin{array}{l}-0.051 \\
(0.048)\end{array}$ \\
\hline Self-employment & $\begin{array}{l}0.402 * * \\
(0.205)\end{array}$ \\
\hline Examinations & $\begin{array}{l}0.179 * * \\
(0.084)\end{array}$ \\
\hline Other & $\begin{array}{l}-0.098 \\
(0.066)\end{array}$ \\
\hline UI recipient & $\begin{array}{l}-0.199 * * * \\
(0.057)\end{array}$ \\
\hline Schooling & $\begin{array}{l}0.028 * * * \\
(0.007)\end{array}$ \\
\hline Tenure & $\begin{array}{l}-0.025 * * * \\
(0.005)\end{array}$ \\
\hline Age & $\begin{array}{l}-0.012 * * * \\
(0.003)\end{array}$ \\
\hline Male & $\begin{array}{l}0.203 * * * \\
(0.044)\end{array}$ \\
\hline Married & $\begin{array}{c}0.040 \\
(0.054)\end{array}$ \\
\hline Handicapped & $\begin{array}{l}-0.382 \\
(0.238)\end{array}$ \\
\hline White collar & $\begin{array}{l}-0.148 * * \\
(0.065)\end{array}$ \\
\hline Number of jobs & $\begin{array}{l}0.017 * * * \\
(0.003)\end{array}$ \\
\hline First job & $\begin{array}{l}-0.411 * * * \\
(0.073)\end{array}$ \\
\hline Collective dismissal & $\begin{array}{c}0.113 \\
(0.075)\end{array}$ \\
\hline End fixed-term contract & $\begin{array}{l}0.156^{* * *} \\
(0.052)\end{array}$ \\
\hline
\end{tabular}


Table 2, continued

Year 1993

$-0.217 * * *$

(0.073)

Year 1994

$-0.053$

$(0.072)$

Year 1995

$-0.259 * * *$

(0.076)

Year 1996

$-0.106$

$(0.784)$

Region A: Algarve

$-0.231 * *$

(0.096)

Region B: Central

0.034

$(0.084)$

Region C: Lisbon

$-0.288 * * *$

$(0.068)$

Region D: North

$-0.216 * * *$

(0.069)

Log likelihood

$-6283.296$

$\underline{n}$

16032

Asymptotic standard errors in parentheses.

Notes: $* * *, * *, *$ denote statistical significance at the $.01, .05$, and .10 levels, respectively. The baseline hazard function comprises 11 intervals (see text).

Source: $\quad$ Inquérito ao Emprego, 1992-96. 

Table 3: The Probability of Escaping Unemployment, Disaggregate Results, Piecewise Constant Hazards Regressions, 1992-96

\begin{tabular}{|c|c|c|c|c|c|c|c|c|}
\hline \multirow[b]{3}{*}{ Variable } & \multicolumn{7}{|c|}{ Job Finding Method } & \multirow{3}{*}{$\begin{array}{l}\text { Contacted by } \\
\text { employer } \\
\text { (101 events) }\end{array}$} \\
\hline & $\begin{array}{l}\text { Direct } \\
\text { approach } \\
\text { (491 events) }\end{array}$ & $\begin{array}{l}\text { Friends/ } \\
\text { relatives } \\
\text { (1046 events) }\end{array}$ & $\begin{array}{l}\text { Advertisement } \\
\text { (148 events) }\end{array}$ & $\begin{array}{l}\text { Public employment } \\
\text { agency } \\
\text { (145 events) }\end{array}$ & $\begin{array}{l}\text { Self- } \\
\text { Employment } \\
(173 \text { events })\end{array}$ & $\begin{array}{c}\text { Other } \\
\text { (112 events) }\end{array}$ & $\begin{array}{r}\text { Examinations } \\
\text { (114 events) }\end{array}$ & \\
\hline & & & & & & & & \\
\hline UI recipient & $\begin{array}{l}-0.145 \\
(0.112)\end{array}$ & $\begin{array}{l}-0.221 * * * \\
(0.081)\end{array}$ & $\begin{array}{l}-0.741 * * * \\
(0.247)\end{array}$ & $\begin{array}{l}0.794 * * * \\
(0.197)\end{array}$ & $\begin{array}{l}-0.785^{* * * *} \\
(0.192)\end{array}$ & $\begin{array}{l}-0.284 \\
(0.319)\end{array}$ & $\begin{array}{l}-1.127 * * * \\
(0.315)\end{array}$ & $\begin{array}{c}0.374 * \\
(0.217)\end{array}$ \\
\hline Schooling & $\begin{array}{l}-0.490 * * * \\
(0.017)\end{array}$ & $\begin{array}{l}-0.023 * * \\
(0.010)\end{array}$ & $\begin{array}{l}0.133 * * * \\
(0.024)\end{array}$ & $\begin{array}{c}0.019 \\
(0.029)\end{array}$ & $\begin{array}{l}0.073 * * * \\
(0.023)\end{array}$ & $\begin{array}{l}0.363 * * * \\
(0.030)\end{array}$ & $\begin{array}{l}0.107 * * * \\
(0.027)\end{array}$ & $\begin{array}{l}-0.086 * * \\
(0.042)\end{array}$ \\
\hline Tenure & $\begin{array}{l}-0.029 * * * \\
(0.010)\end{array}$ & $\begin{array}{l}-0.020 * * * \\
(0.007)\end{array}$ & $\begin{array}{l}-0.035^{*} \\
(0.021)\end{array}$ & $\begin{array}{l}-0.058 * * \\
(0.023)\end{array}$ & $\begin{array}{l}-0.010 \\
(0.011)\end{array}$ & $\begin{array}{c}0.025 \\
(0.026)\end{array}$ & $\begin{array}{l}-0.047 * * \\
(0.023)\end{array}$ & $\begin{array}{l}-0.031^{*} \\
(0.019)\end{array}$ \\
\hline Age & $\begin{array}{l}-0.035^{* * * *} \\
(0.006)\end{array}$ & $\begin{array}{l}-0.022 * * * \\
(0.004)\end{array}$ & $\begin{array}{l}-0.005 \\
(0.011)\end{array}$ & $\begin{array}{l}-0.009 \\
(0.010)\end{array}$ & $\begin{array}{c}0.014 \\
(0.009)\end{array}$ & $\begin{array}{l}-0.026 \\
(0.020)\end{array}$ & $\begin{array}{c}0.005 \\
(0.012)\end{array}$ & $\begin{array}{c}0.013 \\
(0.011)\end{array}$ \\
\hline Male & $\begin{array}{l}0.364 * * * \\
(0.095)\end{array}$ & $\begin{array}{l}0.189 * * * \\
(0.064)\end{array}$ & $\begin{array}{c}0.242 \\
(0.170)\end{array}$ & $\begin{array}{l}-0.262 \\
(0.176)\end{array}$ & $\begin{array}{c}0.857 \\
(0.171)\end{array}$ & $\begin{array}{l}-0.173 \\
(0.204)\end{array}$ & $\begin{array}{c}0.237 \\
(0.195)\end{array}$ & $\begin{array}{l}-0.164 \\
(0.214)\end{array}$ \\
\hline Married & $\begin{array}{l}0.258 * * \\
(0.116)\end{array}$ & $\begin{array}{l}-0.166^{* *} \\
(0.081)\end{array}$ & $\begin{array}{l}-0.012 \\
(0.217)\end{array}$ & $\begin{array}{l}-0.174 \\
(0.205)\end{array}$ & $\begin{array}{l}0.967 * * * \\
(0.213)\end{array}$ & $\begin{array}{c}0.211 \\
(0.272)\end{array}$ & $\begin{array}{c}0.011 \\
(0.246)\end{array}$ & $\begin{array}{c}0.404 \\
(0.260)\end{array}$ \\
\hline Handicapped & $\begin{array}{l}-0.710 \\
(0.582)\end{array}$ & $\begin{array}{l}-0.340 \\
(0.337)\end{array}$ & - & $\begin{array}{c}0.823 \\
(0.597)\end{array}$ & $\begin{array}{c}0.339 \\
(0.589)\end{array}$ & - & - & - \\
\hline White collar & $\begin{array}{l}-0.408 * * \\
(0.162)\end{array}$ & $\begin{array}{l}-0.011 \\
(0.096)\end{array}$ & $\begin{array}{l}-0.336 \\
(0.235)\end{array}$ & $\begin{array}{c}0.058 \\
(0.255)\end{array}$ & $\begin{array}{c}0.024 \\
(0.212)\end{array}$ & $\begin{array}{l}-0.066 \\
(0.309)\end{array}$ & $\begin{array}{l}-0.261 \\
(0.272)\end{array}$ & $\begin{array}{l}-0.326 \\
(0.414)\end{array}$ \\
\hline Number of jobs & $\begin{array}{l}0.019 * * \\
(0.008)\end{array}$ & $\begin{array}{l}0.017 * * * \\
(0.005)\end{array}$ & $\begin{array}{l}-0.001 \\
(0.026)\end{array}$ & $\begin{array}{l}-0.009 \\
(0.014)\end{array}$ & $\begin{array}{c}0.016 \\
(0.013)\end{array}$ & $\begin{array}{c}0.006 \\
(0.026)\end{array}$ & $\begin{array}{l}-0.012 \\
(0.039)\end{array}$ & $\begin{array}{c}0.003 \\
(0.009)\end{array}$ \\
\hline
\end{tabular}


Table 3, continued

\begin{tabular}{|c|c|c|c|c|c|c|c|c|}
\hline First job & $\begin{array}{l}-0.678 * * * \\
(0.173)\end{array}$ & $\begin{array}{l}-0.273 * * * \\
(0.105)\end{array}$ & $\begin{array}{l}-0.900 * * * \\
(0.271)\end{array}$ & $\begin{array}{l}-0.420 \\
(0.326)\end{array}$ & $\begin{array}{l}-1.037 * * * \\
(0.372)\end{array}$ & $\begin{array}{c}0.409 \\
(0.375)\end{array}$ & $\begin{array}{l}-0.662 * * \\
(0.311)\end{array}$ & $\begin{array}{l}-1.110 \\
(0.768)\end{array}$ \\
\hline $\begin{array}{l}\text { Collective } \\
\text { dismissal }\end{array}$ & $\begin{array}{l}0.517 * * * \\
(0.141)\end{array}$ & $\begin{array}{l}-0.041 \\
(0.116)\end{array}$ & $\begin{array}{l}-0.032 \\
(0.317)\end{array}$ & $\begin{array}{c}0.062 \\
(0.323)\end{array}$ & $\begin{array}{c}0.044 \\
(0.229)\end{array}$ & $\begin{array}{l}-0.095 \\
(0.632)\end{array}$ & $\begin{array}{c}0.066 \\
(0.348)\end{array}$ & $\begin{array}{l}-0.018 \\
(0.426)\end{array}$ \\
\hline $\begin{array}{l}\text { End fixed-term } \\
\text { contract }\end{array}$ & $\begin{array}{c}0.030 \\
(0.113)\end{array}$ & $\begin{array}{r}0.150^{*} \\
(0.077)\end{array}$ & $\begin{array}{l}-0.127 \\
(0.208)\end{array}$ & $\begin{array}{c}0.283 \\
(0.210)\end{array}$ & $\begin{array}{l}-0.252 \\
(0.196)\end{array}$ & $\begin{array}{l}0.899 * * * \\
(0.282)\end{array}$ & $\begin{array}{l}-0.081 \\
(0.242)\end{array}$ & $\begin{array}{l}0.801 * * * \\
(0.275)\end{array}$ \\
\hline Region A: Algarve & $\begin{array}{c}0.243 \\
(0.197)\end{array}$ & $\begin{array}{l}-0.224 \\
(0.147)\end{array}$ & $\begin{array}{l}-1.689 \\
(1.057)\end{array}$ & $\begin{array}{l}-0.530 * * \\
(0.268)\end{array}$ & $\begin{array}{c}0.128 \\
(0.335)\end{array}$ & $\begin{array}{l}-0.994 * \\
(0.570)\end{array}$ & $\begin{array}{l}1.238^{* *} \\
(0.619)\end{array}$ & $\begin{array}{l}-1.141 * * \\
(0.447)\end{array}$ \\
\hline Region B: Central & $\begin{array}{l}0.715^{* * * *} \\
(0.166)\end{array}$ & $\begin{array}{l}-0.169 \\
(0.135)\end{array}$ & $\begin{array}{c}0.116 \\
(0.510)\end{array}$ & $\begin{array}{l}-0.797 * * * \\
(0.291)\end{array}$ & $\begin{array}{c}0.230 \\
(0.321)\end{array}$ & $\begin{array}{c}0.372 \\
(0.364)\end{array}$ & $\begin{array}{c}0.941 \\
(0.634)\end{array}$ & $\begin{array}{l}-2.204 * * * \\
(0.732)\end{array}$ \\
\hline Region C: Lisbon & $\begin{array}{l}-0.204 \\
(0.154)\end{array}$ & $\begin{array}{l}-0.174 * \\
(0.099)\end{array}$ & $\begin{array}{c}0.962 \\
(0.362)\end{array}$ & $\begin{array}{l}-1.817 * * * \\
(0.251)\end{array}$ & $\begin{array}{l}-0.096 \\
(0.263)\end{array}$ & $\begin{array}{l}-0.973 * * * \\
(0.332)\end{array}$ & $\begin{array}{l}1.440 * * * \\
(0.529)\end{array}$ & $\begin{array}{l}-0.974 * * * \\
(0.258)\end{array}$ \\
\hline Region D: North & $\begin{array}{l}-0.110 \\
(0.155)\end{array}$ & $\begin{array}{l}-0.032 \\
(0.099)\end{array}$ & $\begin{array}{l}0.788 * * \\
(0.371)\end{array}$ & $\begin{array}{l}-1.820 * * * \\
(0.257)\end{array}$ & $\begin{array}{l}-0.269 \\
(0.277)\end{array}$ & $\begin{array}{l}-0.294 \\
(0.310)\end{array}$ & $\begin{array}{l}1.435 * * * \\
(0.534)\end{array}$ & $\begin{array}{l}-1.543 * * * \\
(0.344)\end{array}$ \\
\hline Log likelihood -204 & 42.321 & -3703.947 & -758.677 & -742.833 & -888.685 & -493.045 & -634.171 & -500.408 \\
\hline$n$ & 16032 & 16032 & 16032 & 16032 & 16032 & 16032 & 16032 & 16032 \\
\hline
\end{tabular}

Asymptotic standard errors in parentheses.

Notes:***,**,* denote statistical significance at the $.01, .05$, and .10 levels, respectively. The job finding categories of self-employment and examinations do not exactly correspond to their counterparts in Tables 1 and 2, while unemployed workers contacted by employers have no job search counterpart.

Source: Inquérito ao Emprego, 1992-96. 
Table 4: Earnings Determination by Job-Finding Method, Grouped Regression, Log-Normal Distribution, 1997

\begin{tabular}{|c|c|c|c|}
\hline \multirow{2}{*}{$\begin{array}{l}\text { Variable } \\
\text { Intercept }\end{array}$} & \multicolumn{3}{|c|}{ Specification } \\
\hline & $\begin{array}{l}4.688^{* * * *} \\
(0.021)\end{array}$ & $\begin{array}{l}2.985^{* * * *} \\
(0.028)\end{array}$ & $\begin{array}{l}3.135^{* * * *} \\
(0.028)\end{array}$ \\
\hline Direct approach & $\begin{array}{l}-0.350 * * * \\
(0.022)\end{array}$ & $\begin{array}{l}-0.095^{* * * *} \\
(0.016)\end{array}$ & $\begin{array}{l}-0.098 * * * \\
(0.015)\end{array}$ \\
\hline Friends/relatives & $\begin{array}{l}-0.340 * * * \\
(0.021)\end{array}$ & $\begin{array}{l}-0.110^{* * * *} \\
(0.015)\end{array}$ & $\begin{array}{l}-0.114 * * * \\
(0.015)\end{array}$ \\
\hline Advertisement & $\begin{array}{l}-0.128 * * * \\
(0.029)\end{array}$ & $\begin{array}{l}-0.083^{* * *} \\
(0.020)\end{array}$ & $\begin{array}{l}-0.051 * * \\
(0.020)\end{array}$ \\
\hline Public employment agency & $\begin{array}{l}-0.486^{* * *} \\
(0.030)\end{array}$ & $\begin{array}{l}-0.215^{* * * *} \\
(0.022)\end{array}$ & $\begin{array}{l}-0.136^{* * * *} \\
(0.021)\end{array}$ \\
\hline Examinations & $\begin{array}{l}0.338^{* * * *} \\
(0.023)\end{array}$ & $\begin{array}{l}0.130 * * * \\
(0.016)\end{array}$ & $\begin{array}{l}0.107 * * * \\
(0.016)\end{array}$ \\
\hline Contacted by employer & $\begin{array}{l}-0.345^{* * *} \\
(0.031)\end{array}$ & $\begin{array}{l}-0.100^{* * * *} \\
(0.022)\end{array}$ & $\begin{array}{l}-0.056^{* * * *} \\
(0.021)\end{array}$ \\
\hline Vocational training & & $\begin{array}{l}0.022 * * \\
(0.010)\end{array}$ & $\begin{array}{c}0.017 * \\
(0.010)\end{array}$ \\
\hline Schooling & & $\begin{array}{l}0.075^{* * * *} \\
(0.001)\end{array}$ & $\begin{array}{l}0.071 * * * \\
(0.001)\end{array}$ \\
\hline Tenure & & - & $\begin{array}{l}0.015 * * * \\
(0.001)\end{array}$ \\
\hline Tenure squared & & - & $\begin{array}{l}-0.0001 * * * \\
(0.00003)\end{array}$ \\
\hline Experience & & $\begin{array}{l}0.036^{* * * *} \\
(0.001)\end{array}$ & $\begin{array}{l}0.024 * * * \\
(0.0001)\end{array}$ \\
\hline Experience squared & & $\begin{array}{l}-0.001 * * * \\
(0.00002)\end{array}$ & $\begin{array}{c}0.0004 * * * \\
(0.00002)\end{array}$ \\
\hline Male & & $\begin{array}{l}0.165^{* * * *} \\
(0.006)\end{array}$ & $\begin{array}{l}0.167 * * * \\
(0.006)\end{array}$ \\
\hline Fixed-term contract & & - & $\begin{array}{l}-0.029 * * * \\
(0.008)\end{array}$ \\
\hline Full-time employment & & $\begin{array}{l}0.475^{* * * *} \\
(0.014)\end{array}$ & $\begin{array}{l}0.427 * * * \\
(0.014)\end{array}$ \\
\hline
\end{tabular}


Table 4, continued

Mining

$0.199 * * *$

(0.052)

Manufacturing

Utilities

Construction

Services

Public administration

Region A: Algarve

Region B: Central

Region C: Lisbon

Region D: North

Log likelihood

$n$

$-34448.00$

14895
$0.061 * * *$

$(0.019)$

$0.215^{* * * *}$

(0.032)

$0.097 * * *$

(0.020)

$0.050 * * *$

(0.019)

$0.079 * * *$

(0.019)

0.005

(0.013)

$-0.053 * * *$

(0.012)

$0.072 * * *$

(0.010)

$-0.044 * * *$

(0.011)

$-29188.26$

14895
$0.148 * * *$

(0.051)

0.018

(0.018)

$0.161 * * *$

(0.031)

$0.114 * * *$

(0.019)

0.022

(0.018)

0.032 *

(0.019)

$-0.010$

(0.013)

$-0.076^{* * *}$

(0.012)

$0.043 * * *$

(0.010)

$-0.081 * * *$

(0.010)

$-28716.48$

14895

Asymptotic standard errors in parentheses.

Notes: $\quad * * *, * *, *$ denote statistical significance at the $.01, .05$, and .10 levels, respectively. The dependent variable is a categorical measure comprising 13 intervals - see text.

Source: Inquérito ao Emprego. 
Table 5: Earnings Determination Across Job-Finding Methods, Log-Normal Distribution, Selected Coefficient Estimates, 1997

\begin{tabular}{|c|c|c|c|c|c|c|c|}
\hline \multirow[b]{3}{*}{ Variable } & \multicolumn{7}{|c|}{ Job Finding Method } \\
\hline & $\begin{array}{l}\text { Direct } \\
\text { approach }\end{array}$ & $\begin{array}{l}\text { Friends/ } \\
\text { relatives }\end{array}$ & Advertisement & $\begin{array}{l}\text { Public employment } \\
\text { agency }\end{array}$ & Other & Examinations & $\begin{array}{c}\text { Contacted by } \\
\text { employer }\end{array}$ \\
\hline & & & & & & & \\
\hline Vocational training & $\begin{array}{l}0.061^{* * * *} \\
(0.022)\end{array}$ & $\begin{array}{l}0.043 * * * \\
(0.015)\end{array}$ & $\begin{array}{c}0.079 * \\
(0.045)\end{array}$ & $\begin{array}{l}-0.039 \\
(0.030)\end{array}$ & $\begin{array}{c}0.090 * \\
(0.049)\end{array}$ & $\begin{array}{l}-0.015 \\
(0.022)\end{array}$ & $\begin{array}{c}0.069 \\
(0.047)\end{array}$ \\
\hline Schooling & $\begin{array}{l}0.057^{* * * *} \\
(0.002)\end{array}$ & $\begin{array}{l}0.066 * * * \\
(0.001)\end{array}$ & $\begin{array}{l}0.074 * * * \\
(0.004)\end{array}$ & $\begin{array}{l}0.042 * * * \\
(0.004)\end{array}$ & $\begin{array}{l}0.083^{* * *} \\
(0.005)\end{array}$ & $\begin{array}{l}0.075^{* * *} * \\
(0.002)\end{array}$ & $\begin{array}{l}0.084 * * * \\
(0.004)\end{array}$ \\
\hline Tenure & $\begin{array}{l}0.009 * * * \\
(0.002)\end{array}$ & $\begin{array}{l}0.015^{* * *} * \\
(0.001)\end{array}$ & $\begin{array}{l}0.028 * * * \\
(0.006)\end{array}$ & $\begin{array}{l}-0.006 \\
(0.008)\end{array}$ & $\begin{array}{c}0.012 \\
(0.007)\end{array}$ & $\begin{array}{l}0.029 * * * \\
(0.003)\end{array}$ & $\begin{array}{l}-0.007 \\
(0.005)\end{array}$ \\
\hline Experience & $\begin{array}{l}0.024 * * * \\
(0.002)\end{array}$ & $\begin{array}{l}0.025^{* * * *} \\
(0.001)\end{array}$ & $\begin{array}{l}0.017 * * * \\
(0.004)\end{array}$ & $\begin{array}{l}0.011^{* * * *} \\
(0.002)\end{array}$ & $\begin{array}{l}0.030^{* * * *} \\
(0.006)\end{array}$ & $\begin{array}{l}0.012 * * * \\
(0.003)\end{array}$ & $\begin{array}{l}0.029 * * * \\
(0.004)\end{array}$ \\
\hline Fixed-term contract & $\begin{array}{l}-0.031 * * \\
(0.014)\end{array}$ & $\begin{array}{l}-0.012 \\
(0.011)\end{array}$ & $\begin{array}{l}-0.089 * * \\
(0.036)\end{array}$ & $\begin{array}{l}-0.109 * * * \\
(0.030)\end{array}$ & $\begin{array}{l}-0.052 \\
(0.046)\end{array}$ & $\begin{array}{l}-0.074 * * * \\
(0.025)\end{array}$ & $\begin{array}{l}-0.003 \\
(0.037)\end{array}$ \\
\hline Public administration & $\begin{array}{l}0.099 * * * \\
(0.036)\end{array}$ & $\begin{array}{l}0.112 * * * \\
(0.026)\end{array}$ & $\begin{array}{c}0.124 \\
(0.313)\end{array}$ & $\begin{array}{l}-0.139 * \\
(0.077)\end{array}$ & $\begin{array}{l}0.395^{* * * *} \\
(0.101)\end{array}$ & $\begin{array}{l}-1.236 * * * \\
(0.163)\end{array}$ & $\begin{array}{c}0.114^{*} \\
(0.063)\end{array}$ \\
\hline Log likelihood & -5836.24 & -14622.60 & -1002.49 & -801.11 & -970.23 & -4218.51 & -776.16 \\
\hline$n$ & 3053 & 7435 & 517 & 444 & 508 & 2506 & 432 \\
\hline
\end{tabular}

Asymptotic standard errors in parentheses.

Notes: $* * *, * *, *$ denote statistical significance at the $.01, .05$, and .10 levels, respectively.

Source: Inquérito ao Emprego. 
Table 6: Probability of Choosing a Job-Finding Method, Multinominal Logit Estimates, 1997

\begin{tabular}{|c|c|c|c|c|c|c|}
\hline \multirow[b]{2}{*}{ Variable } & \multirow[b]{2}{*}{$\begin{array}{l}\text { Direct } \\
\text { approach } \\
\text { (3059 events) }\end{array}$} & \multicolumn{4}{|c|}{ Job Finding Method } & \multirow[b]{2}{*}{$\begin{array}{l}\text { Contacted by } \\
\text { employer } \\
\text { (432 events) }\end{array}$} \\
\hline & & $\begin{array}{l}\text { Friends/ } \\
\text { relatives } \\
\text { (7455 events) }\end{array}$ & $\begin{array}{l}\text { Advertisement } \\
\text { (518 events })\end{array}$ & $\begin{array}{c}\text { Public employment } \\
\text { agency } \\
\text { (444 events) }\end{array}$ & $\begin{array}{l}\text { Examinations } \\
\text { (2528 events) }\end{array}$ & \\
\hline Intercept & $\begin{array}{l}3.369 * * * \\
(0.412)\end{array}$ & $\begin{array}{l}4.193 * * * \\
(0.379)\end{array}$ & $\begin{array}{l}2.375^{* * *} \\
(1.116)\end{array}$ & $\begin{array}{l}2.713^{* * * *} \\
(0.591)\end{array}$ & $\begin{array}{l}1.714 * * * \\
(0.643)\end{array}$ & $\begin{array}{l}2.183 * * * \\
(0.461)\end{array}$ \\
\hline Vocational training & $\begin{array}{l}-0.944 * * * \\
(0.169)\end{array}$ & $\begin{array}{l}-0.782 * * * \\
(0.141)\end{array}$ & $\begin{array}{l}-0.579 * * * \\
(0.201)\end{array}$ & $\begin{array}{c}0.206 \\
(0.219)\end{array}$ & $\begin{array}{l}-0.194 \\
(0.167)\end{array}$ & $\begin{array}{l}-0.499 * * \\
(0.238)\end{array}$ \\
\hline Schooling & $\begin{array}{l}-0.208^{* * * *} \\
(0.015)\end{array}$ & $\begin{array}{l}-0.203 * * * \\
(0.014)\end{array}$ & $\begin{array}{l}-0.062 * * * \\
(0.018)\end{array}$ & $\begin{array}{l}-0.242 * * * \\
(0.025)\end{array}$ & $\begin{array}{l}0.042^{* * * *} \\
(0.014)\end{array}$ & $\begin{array}{l}-0.133 * * * \\
(0.021)\end{array}$ \\
\hline Experience & $\begin{array}{l}0.045^{* * * *} \\
(0.014)\end{array}$ & $\begin{array}{l}0.054 * * * \\
(0.012)\end{array}$ & $\begin{array}{l}0.047 * * * \\
(0.017)\end{array}$ & $\begin{array}{r}-0.0003 \\
(0.021)\end{array}$ & $\begin{array}{l}0.124 * * * \\
(0.014)\end{array}$ & $\begin{array}{l}0.090 * * * \\
(0.019)\end{array}$ \\
\hline Experience squared & $\begin{array}{l}-0.001 * * * \\
(0.0003)\end{array}$ & $\begin{array}{l}-0.001 * * * \\
(0.0003)\end{array}$ & $\begin{array}{l}-0.001 * * * \\
0.0004)\end{array}$ & $\begin{array}{l}-0.0004 \\
(0.0005)\end{array}$ & $\begin{array}{c}0.003 \\
(0.0004)\end{array}$ & $\begin{array}{l}-0.002 * * * \\
(0.0004)\end{array}$ \\
\hline Male & $\begin{array}{l}-0.218^{*} \\
(0.114)\end{array}$ & $\begin{array}{l}-0.343 * * * \\
(0.100)\end{array}$ & $\begin{array}{c}0.205 \\
(0.143)\end{array}$ & $\begin{array}{l}-0.573 * * * \\
(0.176)\end{array}$ & $\begin{array}{l}-0.215^{*} \\
(0.111)\end{array}$ & $\begin{array}{l}-0.276^{*} \\
(0.164)\end{array}$ \\
\hline Mining & $\begin{array}{c}1.519 * \\
(0.843)\end{array}$ & $\begin{array}{c}1.020 \\
(0.739)\end{array}$ & - & - & - & $\begin{array}{c}0.524 \\
(1.463)\end{array}$ \\
\hline Manufacturing & $\begin{array}{l}2.576^{* * * *} \\
(0.289)\end{array}$ & $\begin{array}{l}1.903 * * * \\
(0.268)\end{array}$ & $\begin{array}{l}3.960 * * * \\
(1.040)\end{array}$ & $\begin{array}{l}2.456^{* * * *} \\
(0.526)\end{array}$ & $\begin{array}{l}1.925^{* * * *} \\
(0.573)\end{array}$ & $\begin{array}{l}1.108^{* * * *} \\
(0.353)\end{array}$ \\
\hline Utilities & $\begin{array}{l}2.557 * * * \\
(0.570)\end{array}$ & $\begin{array}{l}1.664 * * * \\
(0.533)\end{array}$ & $\begin{array}{l}4.142 * * * \\
(1.187)\end{array}$ & $\begin{array}{c}2.045 \\
(1.284)\end{array}$ & $\begin{array}{l}2.861 * * * \\
(0.777)\end{array}$ & $\begin{array}{c}0.484 \\
(1.020)\end{array}$ \\
\hline
\end{tabular}


Table 6, continued

\begin{tabular}{|c|c|c|c|c|c|c|}
\hline Construction & $\begin{array}{l}2.455 * * * \\
(0.359)\end{array}$ & $\begin{array}{l}2.285^{* * * *} \\
(0.340)\end{array}$ & $\begin{array}{l}3.994 * * * \\
(1.074)\end{array}$ & $\begin{array}{l}1.566^{* * *} \\
(0.652)\end{array}$ & $\begin{array}{c}0.509 \\
(0.791)\end{array}$ & $\begin{array}{c}0.913 * * \\
(0.449)\end{array}$ \\
\hline Services & $\begin{array}{l}1.535 * * * \\
(0.278)\end{array}$ & $\begin{array}{l}1.718^{* * * *} \\
(0.256)\end{array}$ & $\begin{array}{l}4.264 * * * \\
(1.034)\end{array}$ & $\begin{array}{l}1.704 * * * \\
(0.517)\end{array}$ & $\begin{array}{l}2.628 * * * \\
(0.558)\end{array}$ & $\begin{array}{c}0.291 \\
(0.344)\end{array}$ \\
\hline Public administration & $0.871 * * *$ & $0.652 * *$ & $2.675^{* *}$ & $2.121 * * *$ & $3.92 * * *$ & -0.452 \\
\hline & $(0.289)$ & $(0.262)$ & $(1.043)$ & $(0.518)$ & $(0.559)$ & $(0.380)$ \\
\hline Region A: Algarve & $\begin{array}{l}-0.758^{* *} \\
(0.381)\end{array}$ & $\begin{array}{l}-0.885^{* *} \\
(0.366)\end{array}$ & $\begin{array}{l}-2.156 * * * \\
(0.579)\end{array}$ & $\begin{array}{l}-1.690 * * * \\
(0.408)\end{array}$ & $\begin{array}{l}1.084 * * * \\
(0.390)\end{array}$ & $\begin{array}{l}-1.954 * * * \\
(0.462)\end{array}$ \\
\hline Region B: Central & $\begin{array}{l}-1.245^{* * *} \\
(0.351)\end{array}$ & $\begin{array}{l}-1.755^{* * * *} \\
(0.336)\end{array}$ & $\begin{array}{l}-1.484 * * * \\
(0.460)\end{array}$ & $\begin{array}{l}-2.515 * * * \\
(0.393)\end{array}$ & $\begin{array}{l}-1.351 * * * \\
(0.350)\end{array}$ & $\begin{array}{l}-1.504 * * * \\
(0.409)\end{array}$ \\
\hline Region C: Lisbon & $\begin{array}{l}-1.665 * * * \\
(0.327)\end{array}$ & $\begin{array}{l}-1.351 * * * \\
(0.311)\end{array}$ & $\begin{array}{l}-0.965^{* *} \\
(0.400)\end{array}$ & $\begin{array}{l}-3.037 * * * \\
(0.349)\end{array}$ & $\begin{array}{l}-1.661 * * * \\
(0.326)\end{array}$ & $\begin{array}{l}-2.261 * * * \\
(0.374)\end{array}$ \\
\hline Region D: North & $\begin{array}{l}-2.031 * * * \\
(0.327)\end{array}$ & $\begin{array}{l}-1.354 * * * \\
(0.312)\end{array}$ & $\begin{array}{l}-0.958 * * \\
(0.403)\end{array}$ & $\begin{array}{l}-2.914 * * * \\
(0.346)\end{array}$ & $\begin{array}{l}-1.382 * * * \\
(0.327)\end{array}$ & $\begin{array}{l}-2.769 * * * \\
(0.378)\end{array}$ \\
\hline$\check{\div}^{2}$ & 719.82 & 631.79 & 189.90 & 421.69 & 556.30 & 329.79 \\
\hline$\underline{n}$ & 3575 & 7971 & 1034 & 960 & 3044 & 948 \\
\hline
\end{tabular}

Asymptotic standard errors in parentheses.

Notes: $* * *, * *, *$ denote statistical significance at the $.01, .05$, and .10 levels, respectively.

Source: Inquérito ao Emprego. 
Table 7: $\quad$ Transitions from Employment into Unemployment 1994-97 by Job Finding Method, Logit Estimates

Variable

Specification

Intercept

$-2.478 * * *$

(0.219)

$-0.020$

(0.188)

Friends/relatives

0.117

(0.183)

$0.489 * *$

(0.213)

Public employment agency

Examinations

Contacted by employer

Schooling

Male

Age

Tenure

Fixed-term contract

Full-time employment

$\div^{2}$

$n$
$1.497 * * *$

(0.207)

$-1.099 * * *$

(0.228)

$0.794 * * *$

(0.204)

$-0.082 * * *$

(0.009)

$-0.185^{* * *} *$

(0.053)

$-0.041 * * *$

(0.002)

785.36

127663
-3.650 ***

(0.227)

0.131

(0.190)

0.257

(0.184)

$0.382 *$

(0.215)

$0.858 * * *$

(0.210)

$-0.714 * * *$

(0.230)

$0.666^{* * * *}$

(0.206)

$-0.075 * * *$

(0.009)

$-0.150 * * *$

(0.055)

$-0.006 * *$

(0.003)

$-0.008 * * *$

(0.001)

$1.315 * * *$

(0.062)

$0.229 *$

(0.118)

1992.30

127618

Asymptotic standard errors in parentheses.

Notes: $\quad * * *, * *, *$ denote statistical significance at the $.01, .05$, and .10 levels, respectively. The number of transitions from employment into unemployment is 1445 .

Source: Inquérito ao Emprego. 


\section{Appendix}

Appendix Table 1: Factors Influencing Search Intensity (Number of Search Methods Used) 1992-96, Maximum Likelihood Estimates of a Truncated Poisson Model

\begin{tabular}{|c|c|}
\hline Variable & Coefficient \\
\hline UI recipient & $\begin{array}{c}0.146 * * * \\
(0.017)\end{array}$ \\
\hline Schooling & $\begin{array}{l}0.032 * * * \\
(0.002)\end{array}$ \\
\hline Tenure & $\begin{array}{l}-0.005 * * * \\
(0.001)\end{array}$ \\
\hline Age & $\begin{array}{l}0.004 * * * \\
(0.001)\end{array}$ \\
\hline Male & $\begin{array}{l}0.107 * * * \\
(0.014)\end{array}$ \\
\hline Married & $\begin{array}{l}-0.044 * * \\
(0.018)\end{array}$ \\
\hline Handicapped & $\begin{array}{c}0.036 \\
(0.068)\end{array}$ \\
\hline White collar & $\begin{array}{l}0.128 * * * \\
(0.020)\end{array}$ \\
\hline Number of jobs & $\begin{array}{c}0.002 * * \\
(0.0001)\end{array}$ \\
\hline First job & $\begin{array}{l}-0.094 * * * \\
(0.025)\end{array}$ \\
\hline Collective dismissal & $\begin{array}{l}0.061 * * * \\
(0.022)\end{array}$ \\
\hline End fixed-term contract & $\begin{array}{l}0.044 * * \\
(0.018)\end{array}$ \\
\hline Unemployment rate & $\begin{array}{l}0.078^{* * *} \\
(0.007)\end{array}$ \\
\hline \multicolumn{2}{|l|}{ Duration (months) } \\
\hline 1 & $\begin{array}{l}-0.539 * * * \\
(0.061)\end{array}$ \\
\hline 2 & $\begin{array}{l}-0.364 * * * \\
(0.062)\end{array}$ \\
\hline 3 & $\begin{array}{l}-0.354 * * * \\
(0.063)\end{array}$ \\
\hline 4 & $\begin{array}{l}-0.338^{* * *} \\
(0.064)\end{array}$ \\
\hline 5 & $\begin{array}{l}-0.336 * * * \\
(0.066)\end{array}$ \\
\hline 6 & $-0.031 * * *$ \\
\hline
\end{tabular}


Table 1, continued

\begin{tabular}{cc}
\hline Variable & Coefficient \\
\hline $7-9$ & $-0.281^{* * *}$ \\
& $(0.061)$ \\
$10-12$ & $-0.243^{* * *}$ \\
& $(0.061)$ \\
$13-18$ & $0.157^{* *}$ \\
& $(0.061)$ \\
$19-24$ & $-0.200^{* *}$ \\
& $(0.063)$ \\
$>24$ & $-0.160^{* * *}$ \\
& $(0.061)$ \\
Region A: Algarve & $0.318^{* * *}$ \\
& $(0.031)$ \\
Region B: Central & $0.100^{* * *}$ \\
& $(0.032)$ \\
Region C: Lisbon & 0.020 \\
& $(0.025)$ \\
Region D: North & $0.138^{* * *}$ \\
&
\end{tabular}

Asymptotic standard errors in parentheses.

Notes: $\quad * * *, * *, *$ denote statistical significance at the $.01, .05$, and .10 levels, respectively. The model is a truncated Poisson regression because zero search methods are not observed.

Source: Inquérito ao Emprego. 
Table 2: The Probability of Being Employed Under a Fixed-Term Contract (Versus Open-Ended Employment) by Job-Finding Method, Logit Estimates, 1997

\section{$\overline{\text { Variable }}$}

Intercept

Direct approach

Friends/relatives

Advertisement

Public employment agency

Examinations

Contacted by employer

Vocational training

Schooling

Experience

Experienced squared

Male

Mining

Manufacturing

Utilities

Construction

Services

Public administration

\section{Coefficient}

$1.843 * * *$

$(0.184)$

$-0.376^{* * * *}$

$(0.118)$

$-0.501 * * *$

(0.111)

0.163

(0.147)

$1.278^{* * *}$

$(0.152)$

$-0.897 * * *$

(0.126)

$-0.335^{* *}$

(0.166)

$-0.056$

$(0.082)$

$-0.037 * * *$

$(0.007)$

$-0.157 * * *$

(0.006)

$0.003^{* * *}$

$(0.0001)$

$-0.084 *$

(0.047)

$-1.630^{* * *}$

$(0.556)$

$0.545^{* * * *}$

$(0.135)$

$-0.427$

$(0.265)$

$-0.032$

(0.131)

$-0.423 * * *$

(0.131)

$-0.267^{*}$

(0.139) 
Table 2, continued

Variable

Region A: Algarve

Region B: Central

Region C: Lisbon

Region D: North

$\div 2$

$n$

Asymptotic standard errors in parentheses.

Notes: $\quad * * *, * *, *$ denote statistical significance at the $.01, .05$, and .10 levels, respectively. The number of fixed-term contracts is 3063 .

\section{Coefficient}

$-0.504 * * *$

(0.096)

$(0.096)$

$-0.634 * * *$

(0.075)

$-1.187 * * *$

(0.076)

2217.32

14952
$-1.234 * * *$ 